\section{International Scientific Journal Theoretical \& Applied Science}

p-ISSN: 2308-4944 (print) e-ISSN: 2409-0085 (online)

Year: $2016 \quad$ Issue: 11 Volume: 43

Published: 03.11.2016 http://T-Science.org

SECTION 8. Architecture and construction.
Viktor Zakharchuk

Head of geodetic group, Stikon Ltd.

Odessa, Ukraine

zvlxxx@gmail.com

Vita Zakharchuk

Assistant

Odessa State Academy of Civil Engineering and

Architecture, Odessa, Ukraine

tzvvxxx@gmail.com

Alexandr Nakhmurov

Professor

Odessa State Academy of Civil Engineering and

Architecture, Odessa, Ukraine nakhmurov09@rambler.ru

Natalia Shyshkalova

Assistant professor

Odessa State Academy of Civil Engineering and

Architecture, Odessa, Ukraine

shishkalova7@mail.ru

Rostyslav Yurkovskyi

Professor

Odessa State Academy of Civil Engineering and

Architecture, Odessa, Ukraine adhimaratma@gmail.com

\title{
ACCURACY OF DETERMINATION OF THE MARKING NETWORK COORDINATES
}

\begin{abstract}
Language: English 11 (43): 62-64.

\section{Introduction}

Increase in volumes of construction works for different purposes and their rising complication demands increase of requirements for engineering and geodetic support, its rationalization and acceleration while maintaining necessary accuracy. External geodetic marking networks is always the original basis of such provision. They are necessary for all processes of engineering maintenance of territory, construction and exploitation of various objects and structures, ranging from surveying, multifactor
\end{abstract}

Abstract: External geodetic network is created on the construction site for rendering in nature the main or center marking axis of buildings (structures), fixing their design parameters, implementation of detailed layout works and executive surveys. The possibility of using the electronic total stations Sokkia 610 and 3Ta5P for determination of the planned position of geodetic points of the external marking net on the building site is being studied. For that theoretical accuracy of determination of geodetic points' coordinates is being compared. The accuracy is calculated on the basis of the nameplate data of the instruments and real values of mean squared errors of the coordinates' determination by these devices by the polar method on the construction site.

Key words: accuracy, marking network, geodetic points, electronic total station, coordinates.

Citation: Zakharchuk V, Zakharchuk V, Nakhmurov A, Shyshkalova N, Yurkovskyi R (2016) ACCURACY OF DETERMINATION OF THE MARKING NETWORK COORDINATES. ISJ Theoretical \& Applied Science,

Soi: http://s-o-i.org/1.1/TAS-11-43-12 Doi: crossef http://dx.doi.org/10.15863/TAS.2016.11.43.12

design, siting and ending with the respective control in the operation of everything created by this project.

The fully recognized principle of such networks' creating is a gradual transition from general to specific and from highly precise measurements to the lower once.

The transfer of the project on site is preceded by surveying, when marking linear and angular elements are calculated by the coordinates of the network points to define the location of themrelatively to the points of the state geodetic planned basis. Meanwhile, depending on the chosen layout method the angular 


\begin{tabular}{|c|c|c|c|c|c|c|}
\hline Impact Factor: & $\begin{array}{l}\text { ISRA (India) } \\
\text { ISI (Dubai, UAE } \\
\text { GIF (Australia) } \\
\text { JIF }\end{array}$ & $\begin{array}{r}=1.344 \\
=0.829 \\
=0.564 \\
=1.500\end{array}$ & $\begin{array}{l}\text { SIS (USA) } \\
\text { PИНЦ (Russia) } \\
\text { ESJI (KZ) } \\
\text { SJIF (Morocco) }\end{array}$ & $\begin{array}{l}=0.912 \\
=0.234 \\
=1.042 \\
=\mathbf{2 . 0 3 1}\end{array}$ & $\begin{array}{l}\text { ICV (Poland) } \\
\text { PIF (India) } \\
\text { IBI (India) }\end{array}$ & $\begin{array}{l}=6.630 \\
=1.940 \\
=4.260\end{array}$ \\
\hline
\end{tabular}

and linear data must be prepared to be set on the ground from the state geodetic network's points,.

The points of the state geodetic network are the basic framework for marking network's constructing. They are established by the techniques of triangulation, trilateration, polygonometry or satellite. These points are fixed on the ground by the underground centers of various structures laid to a depth of $0.5 \mathrm{~m}$ below the maximum freezing depth to avoid seasonal variations in sign. The special metal marks-hemispheres with a hole-center inside are put in the upper part of the centres. The coordinates of this center are to be determined. If necessary the special exterior signs are placed above the centers to provide visibility in observations from nearby points. Theoretical basis for design of the multi-step instructions is research in ensuring of the measurement errors' distribution patterns and the cumulative impact of these errors on overall accuracy.

\section{Basic research}

If these questions are deeply studied for geodetic networks of different accuracy classes, many important accuracy regulations of the multibit planned engineering-geodetic marking networks have still not been provided. Requirements for their accuracy are specified in the State Building Codes of Ukraine DBN.1.3-2010 "Geodetic works in construction".

Let's consider provision of this accuracy when using electronic total stations Sokkia 610 and 3Ta5P for determination of the planned position of the external marking network's points. Coordinates of these points were determined by the polar method from points of the State geodetic network, by measuring with the total station of:

- the angle $\boldsymbol{\beta}$ between the initial side (baseline) connecting the points of the State geodetic network, and direction on the defined point of the external marking network;

- the distance $d$ up to this point.

Moreover, in choosing location of the external network's center point the angle $\boldsymbol{\beta}$ must be less than $90^{\circ}$, the distance $d$ should not exceed the length of the basis.

Theoretically, mean squared errors of measurements by these devices are [1,2]:

For the total station 3Ta5P:

horizontal angle $m_{\beta}= \pm 5^{\prime \prime \prime}$,

vertical angle $m_{V}= \pm 7^{\prime \prime \prime}$,

slope distance $m_{D}= \pm\left(5+3 \cdot 10^{-6} \mathrm{D}\right) \mathrm{mm}$.

For the Sokkia Set 610 total station:

horizontal angle $m_{\beta}= \pm 6$

vertical angle $m_{V}= \pm 6^{\prime \prime}$

slope distance $m_{D}= \pm\left(5+5 \cdot 10^{5} \mathrm{D}\right) \mathrm{mm}$.
Since the horizontal distance is determined by the formula

$$
d=D \cdot \cos v,
$$

then its mean squared deviation is

$$
m_{d}=\sqrt{\cos ^{2} v \cdot m_{D}^{2}+D^{2} \cdot \sin ^{2} v \cdot \frac{m_{v}^{2}}{\rho^{2}}}
$$

For the studied object distance $\mathrm{D}$ between the marking network's points are equal to $10-100 \mathrm{~m}$, and the vertical angles $v$ constitute from $0^{0}$ to $25^{\circ}$.

Then for $D_{\max }=100 \mathrm{~m}$, the mean squared error for the total station $3 \mathrm{Ta} 5 \mathrm{P}$ is:

$m_{d} \approx \pm 5,3 \mathrm{~mm}$ for angle $v=0^{0}$, and

$m_{d} \approx \pm 5,0 \mathrm{~mm}$ for angle $v=25^{\circ}$.

For the Sokkia SET610 total station:

$m_{d} \approx \pm 5,0 \mathrm{~mm}$ for angle $v=0^{0}$, and

$m_{d} \approx \pm 5,1 \mathrm{~mm}$ for angle $v=25^{\circ}$.

Thus, the mean squared error of determining the horizontal distance for the total station 3Ta5P does not exceed $\pm 5.3 \mathrm{~mm}$. For the Sokkia SET610 total station it does not exceed $\pm 5.1 \mathrm{~mm}$. Coordinates are calculated by the formulas:

$$
\begin{aligned}
& x=d \cdot \cos \beta \\
& y=d \cdot \sin \beta
\end{aligned}
$$

Hence their standard errors are respectively equal to

$$
\begin{aligned}
& m_{x}=\sqrt{m_{d}^{2} \cdot \cos ^{2} \beta+d^{2} \cdot \sin ^{2} \beta \cdot \frac{m_{\beta}^{2}}{\rho^{2}}} \\
& m_{y}=\sqrt{m_{d}^{2} \cdot \sin ^{2} \beta+d^{2} \cdot \cos ^{2} \beta \cdot \frac{m_{\beta}^{2}}{\rho^{2}}}
\end{aligned}
$$

The total station 3Ta5P:

When $\mathrm{d}=100 \mathrm{~m}$ for $\beta=0^{0}$ the maximum value is $m_{x}= \pm 5,3 \mathrm{~mm}$, and for $\beta=25^{0}$ the ultimate meaning is $m_{y}= \pm 5,3 \mathrm{~mm}$.

The Sokkia Set 610 total station:

When $\mathrm{d}=100 \mathrm{~m}$ for $\beta=0^{0}$ the maximum value is $m_{x}= \pm 5,1 \mathrm{~mm}$, and for $\beta=25^{0}$ the ultimate meaning is $m_{y}= \pm 5,1 \mathrm{~mm}$.

Under influence of the errors $m_{x}$ and $m_{y}$ accuracy of determination of the planned position of the marking network's point is:

$$
M^{2}=m_{x}^{2}+m_{y}^{2}
$$

or according to the formulas (4):

$$
M^{2}=m_{d}^{2}+\frac{d^{2} \cdot m_{\beta}^{2}}{\rho^{2}}
$$




\begin{tabular}{|c|c|c|c|c|c|c|}
\hline Impact Factor: & $\begin{array}{l}\text { ISRA (India) } \\
\text { ISI (Dubai, UAE } \\
\text { GIF (Australia) } \\
\text { JIF }\end{array}$ & $\begin{array}{l}=1.344 \\
=0.829 \\
=0.564 \\
=1.500\end{array}$ & $\begin{array}{l}\text { SIS (USA) } \\
\text { PUHЦ (Russia) } \\
\text { ESJI (KZ) } \\
\text { SJIF (Morocco) }\end{array}$ & $\begin{array}{l}=0.912 \\
=0.234 \\
=1.042 \\
=2.031\end{array}$ & $\begin{array}{l}\text { ICV (Poland) } \\
\text { PIF (India) } \\
\text { IBI (India) }\end{array}$ & $\begin{array}{l}=6.630 \\
=1.940 \\
=4.260\end{array}$ \\
\hline
\end{tabular}

When $\mathrm{d}=100 \mathrm{~m}$, the ultimate mean squared error of displacement of the marking network's point for the total station 3Ta5P is:

$$
M= \pm 5.9 \mathrm{~mm}
$$

and for the Sokkia Set 610 total station is:

$$
M= \pm 5.0 \mathrm{~mm}
$$

The complexity of the setting and vertical retention of the reflector at marking points produces numerous errors, primarily by the reduction.

Therefore, to evaluate the real accuracy when the points are mutually visible, the planned position of five or three points was determined by two or three points of the State geodetic network, respectively.

The real mean squared error of the marking points according to the results:

- of double measurements is equal to $M= \pm 5.7 \mathrm{~mm}$,

- of triple measurements is $M= \pm 5.3 \mathrm{~mm}$,

- and of theoretical survey, for such amount of measurements respectively equals to $\pm 4.2 \mathrm{~mm}$, $\pm 3.4 \mathrm{~mm}$.

\section{Conclusion}

After analysis of the obtained results one can make the conclusions:

1. Use of electronic total stations Sokkia SET 610 and 3Ta5P provides accuracy in determination of surveying points by polar method while constructuring the external center network at the construction site.

2. In difficult conditions of installation and vertical retention of the reflector on the pipe the real accuracy of determination of the marking points' planned position by the electronic total stations Sokkia Set 610 and 3Ta5P is $25-30 \%$ lower than theoretical accuracy.

3. The accuracy of determination of the planned position is almost independent from the number of measurements (methods).

\section{References:}

1. (2016) Takheometr elektronnyi 3Ta5R. Instruktsiia z ekspluatatsii «Uralskyi optykomekhanichnyi zavod»).

2. (2016) Takheometr elektronnyi Sokkia 610. Instruktsiia z ekspluatatsii, Yaponiia.

3. Kostetska YM (2000) Heodezychni prylady. Ch.II. Elektronni heodezychni prylady. Lviv: IZMN, 2000. - 324 p.

4. Voitenko SP (2012) Heodezychni roboty v budivnytstvi / S.P.Voitenko. - K.: Znannia, 2012. $-574 \mathrm{p}$.

5. (2010) DBN V.1.3.-2:2000 Systema zabezpechennia tochnosti heometrychnykh parametriv u budivnytstvi. Heodezychni roboty v budivnytstvi. Kyiv: Minrehionbud, 2010. - 70 p.

6. (2000) Osnovni polozhennia stvorennia Derzhavnoi heodezychnoi merezhi. Zatverdzheni Postanovoiu Kabinetu Ministriv Ukrainy vid 8.06.1998 № 844. Zakonodavchi ta normatyvni akty. - Ch.1., Vinnytsia: Ateks, 2000. - pp. 408.

7. (2007) KUP UHK 0001:2008. Stvorennia ta rekonstruktsiia miskykh heodezychnykh merezh v USK-200. [Instruktsiia] / KUP UHK 0001:2008. Kyiv: Ukrheodezkartohrafiia, 2007. $-55 \mathrm{p}$.

8. (1998) Zakon Ukrainy «Pro topohrafoheodezychnu i kartohrafichnu diialnist» № 353IV vid 23 hrudnia 1998 roku.

9. (1998) Instruktsiia $\mathrm{z}$ topohrafichnoho znimannia u masshtabakh 1:5000, 1:2000, 1:1000, 1:500. HKNTA-2.04-02-98. Kyiv, 1998.

10. (1994) Osnovni polozhenia stvorennia topohrafichnykh planiv masshtabom 1:2000, 1:1000 ta 1:500. Zatverdzheni Holovnym upravlinniam heodezii, kartohrafii ta kadastru Ukrainy (Nakaz № 3 vid 24.010.1994). 